\title{
The Effects of Vermicompost on Yield and Some Growth Parameters of Lettuce
}

\author{
Alper Durak*, Özlem Altuntaş, İbrahim Kutalmış Kutsal, Rabia Işık, Fırat Ege Karaat
}

Department of Horticulture, Agriculture Faculty, İnönü University, 44100 Battalgazi/Malatya, Turkey

\begin{tabular}{l} 
A R T I C L E I N F O \\
Research Article \\
Received 05 August 2017 \\
Accepted 25 October 2017 \\
\hline
\end{tabular}

Keywords:

Soil organic matter

Vermicompost

Soil quality

Lettuce

Yield

*Corresponding Author:

E-mail: alper.durak@inonu.edu.tr

\begin{abstract}
A B S T R A C T
Due to its importance for organic agriculture, one of the most important agricultural production systems, various sources have been proposed to increase soil organic matter content. Vermicompost is one of those sources known as the resistant last form of farmyard manure which is degraded by earthworms. Soil organic matter or humus and their compounds are nutrient sources that increase physical, chemical and biological quality of soil. Humus and humus compounds improve soil physical, chemical and biological quality parameters increasing rhizosphere aeration and water holding capacity, rehabilitating soil structure, providing plant nutrients and constituting natural media for microorganisms with their regulative effects on soil reactions. In this study, the effects of vermicompost on yield and some growth parameters of lettuce were investigated. For this purpose, a random block designed experiment with 5 different applications was conducted in 3 replicates. The applications were control, vermicompost applications of $100 \mathrm{~kg}, 200 \mathrm{~kg}$ and $300 \mathrm{~kg}$ per decare and conventional fertilization. According to the results obtained, yield and growth parameters were improved by vermicompost application when compared to control and conventional fertilization. As a result of this study, it was concluded that $300 \mathrm{~kg}$ vermicompost/da is a promising application in lettuce production for optimal yield and soil improvement.
\end{abstract}

DOI: https://doi.org/10.24925/turjaf.v5i12.1566-1570.1461

\section{Introduction}

The main objective of agricultural production is to obtain quality crops with optimal yields. This has a direct relation with inputs and methods of the production. Fertilization is one of the most significant factors determining yield and quality. Removal of nutrient deficiencies is achieved via fertilization. On the other hand, agricultural production is not only limited by nutrient deficiency, but also availability of the nutrients is another important factor in agricultural production. The use of organic matter provides significant advantages in obtaining quality crop and optimal yield by increasing availability of the nutrients (Reeves, 1997).

Organic matter influences physical, chemical and biological properties of soil (Tejada et al., 2006). Supplementation of soil with organic matterincreases aggregate formation. Consequently, soil aeration and water holding capacity improve. At the same time, organic matter plays important role in regulation of soil $\mathrm{pH}$ which improves the nutrient uptake. But still the most important impact of organic matter is its biological effects. Organic matter increases the population of the microorganisms which increases soil activity by regulating soil conditions. Because of the aforementioned effects, organic matter has been paid attention in various recent studies and vermicompost has taken its place in those studies as one of the most important organic matter supplementing agent.

Vermicompost significantly improves plant growth and development when applied even in small amounts and it is effectively used in both floriculture and horticulture (Arancon and Edwards, 2005). Vermicompost not only makes plants healthy, qualified and productive, it also regulates plant development with humic acid and hormones. More importantly, it contributes in soil fertility and quality by increasing microbial activity and microbial biomass levels and also prevents destruction of soil borne pests and diseases. Vermicompost is defined as the final part of the organic matter which is resistant to mineralization (Kılıç et al., 1991). Thus, the final part which is resistant to mineralization is obtained by deterioration of the organic matter and it is called as humus which has uttermost importance in fertilization. Humus compounds are quite effective in soil due to both its nutrient and also its humic and fulvic acid contents. Additionally, as a result of slow dissolution character of humus, its effect continues 2-3 years which allows longer fertilization period by preventing annual fertilization. 
Lettuce, the most commonly consumed salad vegetable, is an annual winter crop which can be found in the market during whole year (Aybak, 2002). Since its vegetation period is short and market demand is constant, lettuce production increases each year. On the other hand, cultivation practices especially fertilization and pest management must be performed carefully because lettuce is a leaf vegetable and consumed uncooked.

This study was conducted to observe the effects of vermicompost produced with California red worm on lettuce yield, soil parameters and some other plant properties.

\section{Materials and Methods}

\section{Experimental Details and Treatments}

Location of study area: The study was conducted in Inonu University Battalgazi Campus Research Area, Malatya, Turkey (35.54' and 39.03' North latitudes and $38.45^{\prime}$ and $39.08^{\prime}$ Eastern latitudes). The altitude of the research area is $720 \mathrm{~m}$ above sea level.

Materials: Nissena F1, cos type head lettuce, cultivar were used as plant material. In terms of plant nutrition materials, commercial fertilizers and vermicompost produced from farmyard manure with California red worm were applied. Table 1 includes physical and chemical composition of the vermicompost used in the experiment.

Treatments: The experiment was conducted according to complete randomized block design with 5 different applications in 3 replicates. The applications were; 1) Control, 2) $100 \mathrm{~kg}$ vermicompost/da, 3) $200 \mathrm{~kg}$ vermicompost/da, 4) $300 \mathrm{~kg}$ vermicompost/da and 5) Conventional fertilization.

Control plants were not applied with any fertilizer throughout the vegetation period. For $2^{\text {nd }}, 3^{\text {rd }}$ and $4^{\text {th }}$ applications; different dosages of vermicompost applications were done at once before plantation of lettuce seedlings and no more fertilization were applied. Conventional fertilized parcels were applied with 12 $\mathrm{kg} / \mathrm{da} \mathrm{N}, 10 \mathrm{~kg} / \mathrm{da} \mathrm{P}_{2} \mathrm{O}_{5}$ and $18 \mathrm{~kg} / \mathrm{da} \mathrm{K}_{2} \mathrm{O}$. Whole $\mathrm{P}$ and half of $\mathrm{N}$ and $\mathrm{K}$ were applied before plantation. The rest of $\mathrm{N}$ and $\mathrm{K}$ were applied one month after plantation (Şalk et al., 2008).

Lettuce seedlings were planted on $15^{\text {th }}$ of March 2015 and plants were harvested on $17^{\text {th }}$ of June 2015. Plant cultivation practices were done properly as required for relevant variety and conditions of growing season. It was noted that the growing season was a normal season for the area.

\section{Parameters Examined in Soil Analyses}

Texture (\%) analysis was performed according to Bouyoucos Hydrometer method (Gee and Bouder, 1986). Soil reaction $(\mathrm{pH})$ was measured with glass electrode Neel $\mathrm{pH}$ meter from soil samples diluted to the rate of 1:2.5 with distilled water (Jackson, 1958).

Electrical Conductivity $(\mathrm{EC})(\mathrm{dSm} / \mathrm{cm})$ was measured with EC meter from the soil samples diluted to the rate of 1:2.5 with distilled water (Richards, 1954).
Lime $\left(\% \mathrm{CaCO}_{3}\right)$ was measured by utilization of Scheibler calcimeter (Allison and Moodie, 1965). Organic Matter (\%) was determined according to dichromate oxidation principle with modified Walkley-Black method of wet decomposition (Walkley and Black, 1934). Available Phosphorus (Olsen-P) (mg/kg) was obtained according to Olsen method after $\mathrm{P}$ in the solution was extracted with $\mathrm{NaHO}_{3}$ and measured with spectrometer (Olsen and Dean, 1965).

Exchangeable Potassium (me/100g) was determined with flame photometric measurement performed on the soil samples rinsed and centrifuged 3 times with $1 \mathrm{~N}$ ammonium acetate (Knudsen et al., 1982). Total and extractable $\mathrm{Fe}, \mathrm{Zn}, \mathrm{Cu}$ and $\mathrm{Mn}$ were determined by reading on ASS after filtering on whatman 42 filter paper with $\mathrm{HNO}_{3}$ and $\mathrm{HCl}$ acid mix (1:3 aqua regia) (Baker and Amacher, 1982) and diethylenetriaminepentaacetic acid (DTPA) solution (Lindsay and Norvell, 1978).

\section{Analyses of Plant Nutrient Contents}

Total Nitrogen $(\mathrm{N})$ was determined as total nitrogen in plant by utilization of Kjeldahl method (Chapman and Pratt, 1961).

Total Phosphorus (P) analysis was performed on the solution obtained by dry combustion method from plant samples prepared for analysis by grinding after drying in stove. Results were measured in spectrophotometer with Vanado molibdo phosphoric yellow color method (Barton, 1948). Total Potassium (K) was obtained after plant materials were extracted with $3 \mathrm{~N} \mathrm{HCl}$ and were burned in muffule furnace and then $\mathrm{K}$ in the solutions was determined in flame photometry as described by Kacar (1995). Micronutrients (Fe, Mn, Mg, Zn, Cu) was determined according to dry combustion method by the use of atomic absorption spectrometry (Plank, 1992; Kacar and İnal, 2008).

\section{Statistical Analyses}

For statistical evaluation of obtained data, Duncan test were performed via SPSS 16.0 for Windows software. Variations and differences between different applications were analyzed at the 0.05 significance level.

Table 1 Physical and chemical composition of the vermicompost used in the experiment

\begin{tabular}{|c|c|}
\hline Contents & $\mathrm{C}$ \\
\hline $\mathrm{pH}$ & 8.89 \\
\hline Lime $(\%)$ & 11.3 \\
\hline Organic Matter $(\%)$ & 55 \\
\hline $\mathrm{EC}(\mathrm{mmhos} / \mathrm{cm})$ & 0.009 \\
\hline P (Combustion) (mg/kg) & 9376.46 \\
\hline P (Olsen Method-Available Phosphorus) (mg/kg) & 2193 \\
\hline $\mathrm{K}$ (Dry combustion) $(\mathrm{mg} / \mathrm{kg})$ & 11263.1 \\
\hline $\mathrm{K}$ (Soluted in Ammonium Acetate) $(\mathrm{mg} / \mathrm{kg})$ & 4635 \\
\hline $\mathrm{Ca}$ (Combustion) (mg/kg) & 24366.6 \\
\hline $\mathrm{Ca}$ (Soluted in Ammonium Acetate) $(\mathrm{mg} / \mathrm{kg})$ & 2072.25 \\
\hline $\mathrm{Mg}$ (Dry combustion) (mg/kg) & 4894.80 \\
\hline $\mathrm{Fe}$ (Dry combustion) (mg/kg) & 3797.45 \\
\hline Mn (Dry combustion) (mg/kg) & 275.08 \\
\hline $\mathrm{Zn}$ (Dry combustion) (mg/kg) & 94.95 \\
\hline
\end{tabular}




\section{Results and Discussion}

Inadequate level of organic matter is a limiting factor for growing most of the plant species because of the unique impacts of organic matter on soil. Organic matter improves physical properties of soil and so regulates formation of soil structure, volume-weight and soil pores, water holding capacity, cohesion and adhesion properties, capillarity, color and warm-up speed, permeability and contributes to water and wind erosion resistance. This way organic matter decreases soil volume weight, changes soil structure into granular form, increases soil water holding capacity, manages soil friableness and eases soil cultivation (Karaman et al., 2007).

Together with those physical impacts, organic matter can be counted as a very important input with also its being the only natural $\mathrm{N}$ source, about $1 / 20$ of its total weight is $\mathrm{N}(5-8 \%)$, and providing biological habitat for microorganisms (Kılıç et al., 1991)

The results of soil characteristics and nutrients before plantation and after harvest are given in Table 2 and 3, respectively. When the results of soil analyses performed before plantation and after harvest were compared, some tendencies of increase and decreases were observed on the soil parameters especially on $\mathrm{pH}$ which showed tendency of decrease in such a short vegetation period. Salinity level is another important factor showed tendency of decrease after vermicompost application. While $\mathrm{P}, \mathrm{K}$ and micro nutrient contents decreased because of plant uptake, there was a tendency of increase in organic matter level (Table 2 and 3).

Nutrient contents of the harvested plants are given in Table 4. The leaves of harvested $100 \mathrm{~kg} / \mathrm{da}$ vermicompost applied plants were found as the highest in terms of $\mathrm{K}$ and $\mathrm{Ca}$ contents. In terms of $\mathrm{Mg}, \mathrm{Fe}, \mathrm{Mn}$ and $\mathrm{Zn}$ contents, 300 $\mathrm{kg} / \mathrm{da}$ vermicompost applied plants were found significantly higher compared to other applications. The highest $\mathrm{Cu}$ content was obtained by $200 \mathrm{~kg} / \mathrm{da}$ vermicompost application.

The results of yield and plant growing parameters after vermicompost application are given in Table 5 . Accordingly, in terms of head circumference and root collar diameter the differences between the applications were not found statistically significant $(\mathrm{P}>0.05)$. However, differences between applications for plant height were found statistically significant $(\mathrm{P}<0.05)$. 300 $\mathrm{kg} / \mathrm{da}$ vermicompost applied lettuces had the highest plant height at the harvest. This was followed by the rest of the vermicompost applied plants in different dosages and the lowest plant height was found in the parcels where conventional fertilization was applied (Table 5).

When yield values were statistically evaluated by Duncan's test in 0.05 significance level, $300 \mathrm{~kg} / \mathrm{da}$ vermicompost applied parcels were found as the highest whereas control parcels were found as the lowest yielding parcel (Table 5 and Figure 1).

Recent studies showed that increasing impact of vermicompost on plant growth is caused by its increasing humic acid content (Atiyeh et al., 2000a; Atiyeh et al., 2000b). Plant growth regulators and symbiotic microorganisms (Atiyeh et al., 2002; Arancon et al, 2004), growth hormones and other hormones are absorbed by humic acid during the process of vermicompost production (Edwards et al., 2006). Supplementation of soil with vermicompost develops plant growth by increasing humic acid content and consequently increases plant growth hormones and other beneficial symbiotic microorganisms. Besides, it helps availability of plant nutrients by improving soil structure and microorganism activity and also this way increases plant growth and yield.

Table 2 Soil characteristics of experiment field

\begin{tabular}{l|ccccc}
\hline \multicolumn{1}{c}{ Sampling Period } & Texture & $\mathrm{pH}$ & Salinity (\%) & Lime (\%) & Organic Matter (\%) \\
\hline Before Plantation & $\mathrm{CL}$ & 7.49 & 000.6 & 39.9 & 1.92 \\
After Harvest & $\mathrm{CL}$ & 7.45 & 000.5 & 39.9 & 1.97 \\
\hline
\end{tabular}

Table 3 Nutrient analysis results of experimental field soil

\begin{tabular}{l|cccccccc}
\hline \multirow{2}{*}{ Sampling Period } & \multicolumn{7}{c}{ Nutrients $(\mathrm{mg} / \mathrm{kg})$} \\
\cline { 2 - 8 } & $\mathrm{P}$ & $\mathrm{K}$ & $\mathrm{Ca}$ & $\mathrm{Mg}$ & $\mathrm{Fe}$ & $\mathrm{Mn}$ & $\mathrm{Zn}$ & $\mathrm{Cu}$ \\
\hline Before Plantation & 9.00 & 526.15 & 4038.46 & 689.18 & 0.59 & 6.42 & 0.58 & 2.55 \\
After Harvest & 7.58 & 497.73 & 4200.00 & 765.53 & 0.63 & 21.9 & 0.68 & 2.85 \\
\hline
\end{tabular}

Table 4 Nutrient contents of harvested plants

\begin{tabular}{l|cccccccc}
\hline \multirow{2}{*}{ Application } & $\mathrm{P}$ & $\mathrm{K}$ & $\mathrm{Ca}$ & $\mathrm{Mg}$ & $\mathrm{Fe}$ & $\mathrm{Mn}$ & $\mathrm{Zn}$ & $\mathrm{Cu}$ \\
\cline { 2 - 8 } & $\%$ & $\%$ & $\%$ & $\%$ & $\mathrm{mg} / \mathrm{kg}$ & $\mathrm{mg} / \mathrm{kg}$ & $\mathrm{mg} / \mathrm{kg}$ & $\mathrm{mg} / \mathrm{kg}$ \\
\hline Control & 0.15 & 1.61 & 0.69 & 0.49 & 338.30 & 47.40 & 23.10 & 12.80 \\
$100 \mathrm{~kg}$ & 0.22 & 1.70 & 0.84 & 0.58 & 509.90 & 80.20 & 40.10 & 12.36 \\
$200 \mathrm{~kg}$ & 0.23 & 1.51 & 0.59 & 0.83 & 950.50 & 104.50 & 45.10 & 17.13 \\
$300 \mathrm{~kg}$ & 0.23 & 1.48 & 0.60 & 0.85 & 1139.30 & 107.60 & 54.90 & 15.70 \\
Conventional & 0.25 & 1.44 & 0.44 & 0.75 & 690.50 & 83.30 & 47.90 & 16.79 \\
\hline
\end{tabular}

Table 5 Results of yield and plant growth parameters

\begin{tabular}{l|cccc}
\hline \multicolumn{1}{c}{ Application } & Yield $(\mathrm{kg})$ & Plant Height $(\mathrm{cm})$ & Stem diameter $(\mathrm{cm})$ & Root collar diameter $(\mathrm{cm})$ \\
\hline Control & $19.00 \mathrm{c}$ & $26.43 \mathrm{bc}$ & $36.26 \mathrm{~d}$ & $33.38 \mathrm{~d}$ \\
$100 \mathrm{~kg}$ & $20.16 \mathrm{bc}$ & $19.23 \mathrm{~b}$ & $37.00 \mathrm{~d}$ & $34.15 \mathrm{~d}$ \\
$200 \mathrm{~kg}$ & $21.66 \mathrm{~b}$ & $27.53 \mathrm{~b}$ & $34.76 \mathrm{~d}$ & $34.78 \mathrm{~d}$ \\
$300 \mathrm{~kg}$ & $25.57 \mathrm{a}$ & $34.06 \mathrm{a}$ & $36.43 \mathrm{~d}$ & $35.50 \mathrm{~d}$ \\
Conventional & $19.66 \mathrm{bc}$ & $23.13 \mathrm{c}$ & $29.73 \mathrm{~d}$ & $32.46 \mathrm{~d}$ \\
\hline
\end{tabular}




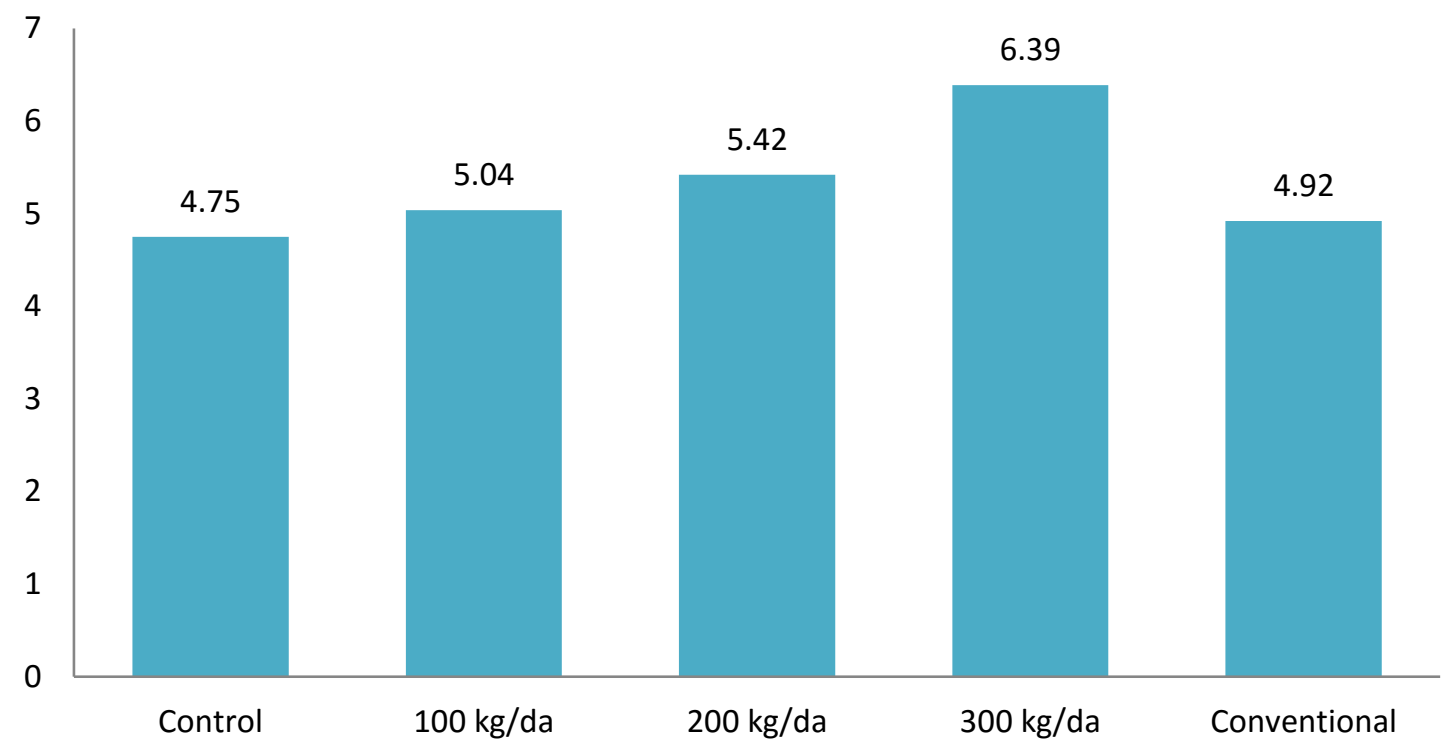

Fig 1 The effects of different vermicompost applications on lettuce yield $\left(\mathrm{kg} / \mathrm{m}^{2}\right)$

\section{Conclusions}

As a result of this present study which was targeted to increase organic matter and available nutrient contents of soil, positive effects of vermicompost applications were observed in soil analyses and in lettuce growth and yield parameters examined in the experiment. It was concluded that vermicompost was an applicable and beneficial organic matter and nutrient source. According to our results, it was further concluded in an economical point of view that $300 \mathrm{~kg} / \mathrm{da}$ vermicompost dosage gave the highest yield and improved most of the growth parameters in lettuce production. On the other hand, since lettuce is a leaf vegetable and so harvested in vegetative growth period, but $\mathrm{P}$ and $\mathrm{K}$ are rather used in generative period. Based on the soil analyses in the experiment, it was observed that vermicompost applications increased $\mathrm{P}$ and $\mathrm{K}$ contents. Therefore, the effects of vermicompost dosages on generative growth and consequently seed yield and quality attributes have to be evaluated in further research studies.

\section{Acknowledgements}

This study was supported by İnönü University Scientific Research Coordination Unit. Project Number: 2014/17(Güd.).

\section{References}

Allison LE, Moodie CD. 1965. Carbonate. In: C.A. Black et al (ed.) Methods of Soil Analysis, Part 2. Agronomy 9:1379-1400. Am. Soc. Of Agron., Inc., Madison, Wisconsin, U.S.A.

Arancon NQ, Edwards CA, Atiyeh RM, Metzger JD. 2004. Effects of vermicompost produced from food waste on the growth and yield of greenhouse peppers. Bioresource Technol., 93: 139144.

Arancon N, Edwards CA. 2005. Effects of vermicomposts on plant growth. International Symposium Workshop on Vermitechnology. Philippines.

Atiyeh RM, Arancon NQ, Edwards CA, Metzger JD, Shuster W, 2000a. Effect of vermicomposts and composts on plant growth in horticulture container media and soil. Pedobiologia, 44: 579590 .
Atiyeh RM, Arancon NQ, Edwards CA, Metzger JD. 2000b. Influence of earthworms-processed pig manure on the growth and yield of greenhouse tomatoes. Bioresource Technol., 75: 175-180.

Atiyeh RM, Arancon NQ, Edwards CA, Metzger JD. 2002. Influence of earthworms-processed pig manure on the growth and productivity of marigolds, Bioresource Technol., 81: 103-108.

Aybak HÇ. 2002. "Salata/marul yetiştiriciliği." Hasad Yayıncılık Ltd. Sti., İstanbul.

Baker ED, Amacher CM. 1982. Nickel, Copper, Zinc, and Cadmium. In Page, A. L., Miller, H. R. \& Keeney, R. D. (eds). Methods of Soil Analysis, Part 2. Am. Agr. and Soil Sci. Am., Madison, Wisconsin USA. pp. 324-334.

Barton CF. 1948. Photometric Analysis of Phosphate Rock. Ind. and Eng. Chem. Anal. Ed., 20: 1068-1073.

Chapman D, Pratt FP. 1961. Methods of Analysis for Soils, Plant and Water, Univ. of California Div. Agr. Sci.

Edwards CA, Arancon NQ, Graytak S. 2006. Effects of vermicompost teas on plant growth and disease. Biocycle. 47 (5): 28-31.

Gee GW, Bouder JW. 1986. Particle Size Analysis. In: Clute (edit). Methods of Soil Analysis. Part I Agronomy No: 9 Am. Soc. of Argon. Madison, Wisconsin, USA.

Jackson ML. 1958. Soil Chemical Analysis, Prentice- Hall. Inc. Englewood Cliffs, N.J. New York.

Kacar B. 1995. Bitki ve Toprağın Kimyasal Analizleri III. A. Ü. Zir. Fak. Ĕg. Arş. Vakfi yay. No: 3, Ankara.

Kacar B, İnal A. 2008. Bitki analizleri. Nobel Yayın Dağıtım, Ankara.

Karaman MR, Brohi AR, Müftüoğlu NM, Öztaş T, Zengin M. 2007. Sürdürülebilir Toprak Verimliliği.Koyulhisar Ziraat Odası Kültür Yayınları No:1

Kılıç M, Brohi AR, Durak A. 1991. Toprak Bilimi. Ders Kitabı, 196 s.

Knudsen D, Peterson GA, Pratt PF. 1982. Lithium, Sodium and Potassium Methods of Soil Analysis, Part 2 Chemical and Microbiological Properties. Agronomy Monograph No: 9 ASASSSA, Wisconsin, USA.

Lindsay WL, Norvell WA. 1978. Development of a DTPA soil test for zinc, iron, manganese and coper. Soil Sci. Soc. Am. J., 42: 421-428.

Olsen SR, Dean LA. 1965. Phosphorus Ed. C. A. Black Methods of Soil Analysis Part 2. American Society of Agronomy Inc. Publisher Madison, Wisconsin, 1035-1049.

Plank CO. 1992. Plant analysis reference procedures for the Southern Region of the United States. So. Coop. Ser. Bull. 368. Ga. Agri. Exp. Sta., Athens. 
Reeves DW. 1997. The role of soil organic matter in maintaining soil quality in continuous cropping systems. Soil Till. Res., 43(1-2), 131-167.

Richards LA. 1954. Diagnosis and Improvement of Saline and Alkaline Soils, US Salinity Laboratory, USDA, Handbook, 60

Şalk A, Arın L, Deveci M, Polat S. 2008. Özel sebzecilik. Tekirdağ2008, 485s.
Tejada M, Garcia C, Gonzalez JL, Hernandez MT. 2006. Use of organic amendment as a strategy for saline soil remediation: influence on the physical, chemical and biological properties of soil. Soil Biol. Biochem., 38(6), 1413-1421.

Walkley A, Black IA. 1934. An Examination of Degtjareff Method for Determining Soil Organic Matter and a Proposed Modification of the Chromic Acid Titration Method. Soil Sci., 37: 29-37. 